\title{
Non-stoichiometric $\mathrm{La}_{(1-x)} \mathrm{NiO}_{(3-\delta)}$ perovskites produced by combustion synthesis
}

\author{
María T. Colomer, ${ }^{a}$ Daniel A. Fumo, ${ }^{b}$ José R. Jurado $^{a}$ and Ana M. Segadães ${ }^{*}$ \\ ${ }^{a}$ CSIC-Instituto de Ceramica y Vidrio, 28500 Arganda del Rey, Madrid, Spain \\ ${ }^{b}$ University of Aveiro, Department of Ceramics and Glass Engineering-UIMC, 3810-193 \\ Aveiro,Portugal.E-mail: segadaes@cv.ua.pt
}

Received 8th April 1999, Accepted 7th July 1999

$\mathrm{La}_{(1-x)} \mathrm{NiO}_{(3-\delta)}$ perovskites present high metallic conductivity and Pauli-paramagnetism, and could be used as electrodes in electrochemical devices such as SOFCs, PEMFCs and MCFCs. Additionally, due to its $\sigma^{*}$ conducting band, this material shows a very high electrocatalytic activity, particularly in oxygen reduction processes, with an efficiency comparable to that of platinum. This work describes the combustion synthesis of $\mathrm{La}_{(1-x)} \mathrm{NiO}_{(3-\delta)}$ perovskite powders $(x=0$ and 0.1$)$ from mixtures of $\mathrm{La}\left(\mathrm{NO}_{3}\right)_{3} \cdot 6 \mathrm{H}_{2} \mathrm{O}$ and $\mathrm{Ni}\left(\mathrm{NO}_{3}\right)_{2} \cdot 6 \mathrm{H}_{2} \mathrm{O}$ as cation precursors, and urea as fuel. The as-prepared combustion product, characterized by XRD, DTA/TG, SEM/TEM, BET and dilatometry (after compaction), shows a much higher specific surface area than powders obtained via alternative routes and contains $\mathrm{La}_{2} \mathrm{NiO}_{4}$ with a typical $\mathrm{K}_{2} \mathrm{NiF}_{4}$-type structure, together with small amounts of $\mathrm{NiO}$. The usual subsequent heat treatments for 1 to $12 \mathrm{~h}$ at successively higher temperatures showed that full conversion to $\mathrm{La}_{(1-x)} \mathrm{NiO}_{(3-\delta)}$ can be readily achieved in air at $750{ }^{\circ} \mathrm{C}$ and that the perovskite, after the $12 \mathrm{~h}$ heat treatment, remains stable up to $1100^{\circ} \mathrm{C}$. These results show that the combustion technique is a better and much simpler route to the synthesis of perovskite powders.

\section{Introduction}

Oxides with the perovskite structure, given the generally high mobility of oxygen ions, are prone to oxygen vacancies and the lanthanum nickel oxide $\mathrm{LaNiO}_{(3-\delta)}$, which displays metallic conduction, finds a possible application as cathodic material in electrochemical devices, such as solid oxide fuel cells (SOFCs), polymer electrolyte membrane fuel cells (PEMFCs) and molten carbonate fuel cells (MCFCs), in which oxygen reduction processes are involved. One of its limitations in this field is instability in the range $750-1100^{\circ} \mathrm{C}$, which includes the device manufacture and/or service temperature, leading to decomposition into $\mathrm{La}_{2} \mathrm{NiO}_{4}$ and $\mathrm{NiO}$, or segregation of $\mathrm{La}_{2} \mathrm{O}_{3}$. This limitation has so far been partially overcome with the use of lanthanum-deficient oxides, $\mathrm{La}_{(1-x)} \mathrm{NiO}_{(3-\delta)}$. Such perovskitetype oxides are known to display catalytic activity for a number of chemical reactions, particularly oxidation processes, and the synthesis of oxygenated organic compounds from hydrocarbons, $\mathrm{CO}_{2}$ and $\mathrm{H}_{2} \cdot{ }^{1-3}$

Matsumoto et al. ${ }^{4}$ reported that the electrocatalytic activity of $\mathrm{LaNiO}_{(3-\delta)}$ is comparable to that of platinum and found that it could be used to produce hydrophobic gas diffusion electrodes with high cathodic currents, ${ }^{5}$ a property which was attributed to the high surface area of the oxide particles. Their results were confirmed by Fierro et $a l^{6}$ who showed that $\mathrm{LaNiO}_{(3-\delta)}$ was one of the best catalysts for oxidation reactions. Differences in catalytic activity have been attributed ${ }^{7}$ to differences in the surface heterogeneity of the samples. Nevertheless, and as stressed earlier by Tseung and Beran, ${ }^{8}$ some improvements were needed regarding the oxide particle sizes.

Single phase $\mathrm{LaNiO}_{(3-\delta)}$ with a BET specific surface area of $4.69 \mathrm{~m}^{2} \mathrm{~g}^{-1}$ has been produced by decomposition in air at $1023 \mathrm{~K}$ of amorphous citrate precursors. ${ }^{6}$ Direct low temperature decomposition of nitrate, oxalate, carbonate and cyanide precursors has also been reported, ${ }^{5,7}$ leading to powders with lower or comparable BET specific surface areas. However, single phase $\mathrm{LaNiO}_{(3-\delta)}$ seems to be more difficult to obtain by this method. There is a general consensus that different synthetic methods lead to different particle morphology and surface roughness, and hence specific surface area which in turn determines the oxide catalytic activity.

The solid state route has seldom been used in the synthesis of the $\mathrm{LaNiO}_{(3-\delta)}$ perovskite as the technique often leads to the presence of secondary phases, unreacted components and, frequently, contamination from grinding in the final product.

Wet chemical synthetic methods, which start with the preparation of a homogeneous liquid solution of the cation ingredients, ${ }^{9-11}$ produce ceramic single or multioxide powders with high sinterability, high surface area, well defined chemical compositions and homogeneous distribution of the elements. Although powder synthesis can be achieved at low temperatures, many solution processes involve sophisticated techniques and complicated procedures which can, technologically, be obstacles to the reproducibility, cost and reliability of the desired powders.

In recent years, combustion synthesis as a preparative process to produce homogeneous very fine crystalline unagglomerated multicomponent oxide ceramic powders without the intermediate decomposition and/or calcining steps has attracted a good deal of attention. ${ }^{12-19}$ Briefly, the combustion synthesis technique consists of bringing a saturated aqueous solution containing the desired metal ions in the form of, for instance, water soluble nitrates and a suitable organic fuel, like urea $\left[\mathrm{CO}\left(\mathrm{NH}_{2}\right)_{2}\right]$, to the boil until the mixture ignites and a selfsustaining and rather fast combustion reaction takes off, resulting in a dry, usually crystalline, fine oxide powder. While redox reactions such as this are exothermic in nature and often lead to explosions if not controlled, the combustion of metal nitrate-urea mixtures usually occurs as a self-propagating and non-explosive exothermic reaction. The large amount of gases formed can result in the appearance of a flame, which can reach temperatures in excess of $1000^{\circ} \mathrm{C}$.

The basis of the combustion synthesis technique comes from the thermochemical concepts used in the field of propellants and explosives. ${ }^{20}$ To calculate the stoichiometric composition of the redox mixture, which corresponds to the release of the maximum energy for the reaction, a simple valency balance is 
established irrespective of whether the elements are present in the oxidizer or the fuel components of the mixture. The assumed valencies are those presented by the elements in the usual products of the combustion reaction, which are $\mathrm{CO}_{2}$, $\mathrm{H}_{2} \mathrm{O}$ and $\mathrm{N}_{2}$. The extrapolation of this concept to the combustion synthesis of ceramic oxides means that metals like La and $\mathrm{Ni}$ (or any other metals) should also be considered as reducing elements with the valencies they have in the corresponding oxides. ${ }^{16}$

The work that follows describes the powder synthesis of lanthanum nickel perovskites by combustion reaction of redox mixtures of the corresponding metal nitrates with urea.

\section{Experimental}

For the combustion synthesis of the $\mathrm{La}_{(1-x)} \mathrm{NiO}_{(3-\delta)}$ perovskites $(x=0$ and 0.1$), \mathrm{Ni}\left(\mathrm{NO}_{3}\right)_{2} \cdot 6 \mathrm{H}_{2} \mathrm{O}$ (Carlo Erba) and $\mathrm{La}\left(\mathrm{NO}_{3}\right)_{3} \cdot 6 \mathrm{H}_{2} \mathrm{O}$ (Merck) were used as cation precursors and urea, $\mathrm{CO}\left(\mathrm{NH}_{2}\right)_{2}$ (Riedel-de Haën), was used as fuel (batches were calculated on the basis of $5 \mathrm{~g}$ of lanthanum nitrate). The reactants were first melted in a wide-mouth vitreous silica basin $\left(300 \mathrm{~cm}^{3}\right)$ by heating up to $c a .300^{\circ} \mathrm{C}$ on a hot-plate inside a fume cupboard, under ventilation. Soon after the liquid began frothing, the basin was transferred to a muffle furnace preheated at $500{ }^{\circ} \mathrm{C}$, where ignition took place. The reaction lasted for 2-3 minutes and produced a dry black and very fragile foam, that readily crumbled into powder.

The as-prepared combustion reaction powders were characterized by X-ray diffraction $\left(\mathrm{Cu}-\mathrm{K} \alpha_{1} / \mathrm{Ni}\right.$, Siemens D5000 diffractometer, $40 \mathrm{~kW}$ and $20 \mathrm{~mA}$, with a scanning rate of 2 $2 \theta \mathrm{min}^{-1}$, using silicon as an internal standard) and Scanning Electron Microscopy (Zeiss DSM-950, $20 \mathrm{kV}$, after Au coating). Powder density was determined with a Quantachrome He multipicnometer and the BET specific surface area with a $\mathrm{He}-$ $\mathrm{N}_{2}$ Monosorb MS-13 instrument. The particle size distribution was determined with a Coulter LS-130 instrument. Powder particles were easily deagglomerated into individual crystals by ultrasonication in isopropyl alcohol and crystallite sizes were determined by Transmission Electron Microscopy ( $\mathrm{LaB}_{6}$ emitter, Hitachi H-9000), after depositing a droplet of the alcoholic suspension onto a copper grid fitted with a cellulosebased film, followed by drying and carbon coating.

The crystallization temperature and phase transformations during heating of $\mathrm{La}_{(1-x)} \mathrm{NiO}_{(3-\delta)}$ were studied in air by XRD as described earlier and by thermal analysis (DTA) carried out with a Netzsch STA-409 instrument, using calcined alumina as the reference material, $\mathrm{Pt}$ crucibles and a constant heating rate of $10^{\circ} \mathrm{C} \mathrm{min}{ }^{-1}$ up to $1400{ }^{\circ} \mathrm{C}$. Oxygen stoichiometry was determined as weight gain upon full oxidation from thermogravimetric experiments carried out on single phase powders (previously calcined at $750^{\circ} \mathrm{C}$ for $8 \mathrm{~h}$ ), kept at $900^{\circ} \mathrm{C}$ for $3 \mathrm{~h}$ under oxygen in a Perkin-Elmer thermoanalyzer, using finely powdered alumina as the reference. The XRD patterns of these powders were also used to calculate lattice parameters.

The sintering behaviour was investigated by dilatometry on uniaxially pressed discs $2-3 \mathrm{~mm}$ thick and $6 \mathrm{~mm}$ in diameter, using a LVDT equipped Netzsch 229402-EP dilatometer with a constant heating rate of $5^{\circ} \mathrm{C} \mathrm{min}-1$ up to $1500^{\circ} \mathrm{C}$.

The processing capabilities of the powders produced were assessed by determining their electrophoretic mobility and zeta potential in aqueous suspensions (distilled water) as a function of $\mathrm{pH}$ with a Malvern ZetaSizer 4 instrument (ZET 5104 cell).

\section{Results and discussion}

\section{Combustion reactions}

To prepare the $\mathrm{LaNiO}_{(3-\delta)}$ perovskite by the combustion route, using urea as fuel, crystalline $\mathrm{Ni}\left(\mathrm{NO}_{3}\right)_{2} \cdot 6 \mathrm{H}_{2} \mathrm{O}$ can be
Table 1 Relevant thermodynamic data ${ }^{21-22}$

\begin{tabular}{lll}
\hline $\mathrm{Compound}^{a}$ & $\Delta H_{\mathrm{f}}^{\mathrm{o}}\left(25^{\circ} \mathrm{C}\right) / \mathrm{kcal} \mathrm{mol}^{-1}$ & $C_{p} / \mathrm{cal} \mathrm{mol}^{-1} \mathrm{~K}^{-1}$ \\
\hline $\mathrm{Ni}\left(\mathrm{NO}_{3}\right)_{2} \cdot 6 \mathrm{H}_{2} \mathrm{O}_{(\mathrm{c})}$ & -528.6 & 111 \\
$\mathrm{La}\left(\mathrm{NO}_{3}\right)_{3} \cdot 6 \mathrm{H}_{2} \mathrm{O}_{\text {(c) }}$ & -732.23 & - \\
$\mathrm{La}\left(\mathrm{NO}_{3}\right)_{3}$ (c) & -299.8 & - \\
$\mathrm{CO}\left(\mathrm{NH}_{2}\right)_{2}$ (c) & -79.71 & 22.26 \\
$\mathrm{LaNiO}_{3}$ (c) & -292.8 & 23.51 \\
$\mathrm{La}_{2} \mathrm{NiO}_{4}{ }_{\text {(c) }}^{24}$ & -486.7 & 38.8 \\
$\mathrm{Ni}_{2} \mathrm{O}_{3}$ (c) & -117.0 & - \\
$\mathrm{NiO}_{(\mathrm{c})}$ & -57.3 & 10.59 \\
$\mathrm{La}_{2} \mathrm{O}_{3}$ (c) & -428.7 & 26.00 \\
$\mathrm{H}_{2} \mathrm{O}_{(\mathrm{g})}$ & -57.796 & $7.20+0.00360 T^{b}$ \\
$\mathrm{CO}_{2}$ (g) & -94.051 & $10.34+0.00274 T^{b}$ \\
$\mathrm{~N}_{2}$ (g) & 0 & $6.50+0.00100 T^{b}$ \\
$\mathrm{O}_{2}(\mathrm{~g})$ & 0 & $5.92+0.00367 T^{b, c}$ \\
${ }_{(\mathrm{c})}$ & $\mathrm{crys}$
\end{tabular}

${ }^{a}(\mathrm{c})=$ crystalline, $(\mathrm{g})=$ gas $.{ }^{b} T=$ absolute temperature.${ }^{c}$ Calculated from discrete values.

used as a Ni source (total valencies -10 ) and $\mathrm{La}\left(\mathrm{NO}_{3}\right)_{3} \cdot 6 \mathrm{H}_{2} \mathrm{O}$ as a $\mathrm{La}$ source (total valencies -15). From published thermodynamic data such as those listed in Table $1,{ }^{21-24}$ the enthalpy change involved in the various chemical reactions can be calculated. The combustion reaction of urea (total valencies +6 ), described by the equation $\mathrm{R} 1$ in Table 2 , is exothermic and should provide the heat needed for the synthesis reaction. The individual decomposition reactions of the precursor nitrates, leading to the corresponding oxides, are also listed in Table 2, as reactions $\mathrm{R} 2$ and $\mathrm{R} 3$, respectively.

The overall synthesis would then be given by the reaction $\mathrm{RT} 1=\mathrm{RS} 1+m \mathrm{R} 1$ (Table 2). For $\mathrm{LaNiO}_{(3-\delta)}$ synthesis, reaction RT1, to occur at $25^{\circ} \mathrm{C} m=2.11 \mathrm{~mol}$ of urea would be needed, solely on the basis of enthalpy change $\left(\Delta H_{\mathrm{RT} 1}^{\mathrm{o}}=0\right)$.

This amount of urea satisfies the enthalpy requirement for complete decomposition at $25^{\circ} \mathrm{C}$ and release of all the corresponding gases, as predicted by reaction RT1 (i.e. $\left.16.22 \mathrm{H}_{2} \mathrm{O}_{(\mathrm{g})}+4.61 \mathrm{~N}_{2(\mathrm{~g})}+2.84 \mathrm{O}_{2(\mathrm{~g})}+2.11 \mathrm{CO}_{2(\mathrm{~g})}\right)$. However, this temperature is not high enough to promote the synthesis of the perovskite and the single oxides (i.e. $\mathrm{NiO}$ and $0.5 \mathrm{La}_{2} \mathrm{O}_{3}$ ) will remain as reaction products.

Direct use of the propellant chemistry criterion, with the metal precursors in a $1: 1$ molar ratio, to determine the urea needed to balance the total oxidizing and reducing valencies in the mixture of oxidizers and fuels, leads to:

$$
(-10)+(-15)+n(+6)=0
$$

In order to release the maximum energy for the reaction, the stoichiometric composition of the redox mixture would demand that $n=4.17 \mathrm{~mol}$ of urea were used. The combustion of the extra 2.06 moles of urea specified by the propellant chemistry calculations will consume all the released oxygen and the heat generated will be absorbed by the resulting gases (i.e. $\left.4.12 \mathrm{H}_{2} \mathrm{O}_{(\mathrm{g})}+2.06 \mathrm{~N}_{2(\mathrm{~g})}+2.06 \mathrm{CO}_{2(\mathrm{~g})}\right)$, the gases already present and the single oxides, raising their temperature. Using the relevant heat capacities listed in Table 1 and the $\Delta H_{\mathrm{R} 1}^{\mathrm{o}}$ value in Table 2, the temperature reached by all the final products would be $857^{\circ} \mathrm{C}$. This temperature should be sufficient to promote perovskite synthesis, although other synthetic methods usually require $12 \mathrm{~h}$ exposures at temperatures in excess of $750{ }^{\circ} \mathrm{C}$ to produce the $\mathrm{LaNiO}_{(3-\delta)}$ phase from a mixture of $\mathrm{La}_{2} \mathrm{NiO}_{4}$ and $\mathrm{NiO}$.

Batches were prepared with $\mathrm{Ni}\left(\mathrm{NO}_{3}\right)_{2} \cdot 6 \mathrm{H}_{2} \mathrm{O}$, $\mathrm{La}\left(\mathrm{NO}_{3}\right)_{3} \cdot 6 \mathrm{H}_{2} \mathrm{O}$ and $\mathrm{CO}\left(\mathrm{NH}_{2}\right)_{2}$ in the molar ratio $1: 1: 4.17$. The mixture ignited easily and, after a short reaction time (2$3 \mathrm{~min}$ ), a dry black foam was produced, accompanied by a large increase in volume when compared to the original volume of liquid. The X-ray diffraction pattern of the as-prepared powder (Fig. 1) showed crystalline $\mathrm{La}_{2} \mathrm{NiO}_{4}$ as the major phase present, together with a small amount of $\mathrm{NiO}$.

This result suggests that the overall reaction is more 


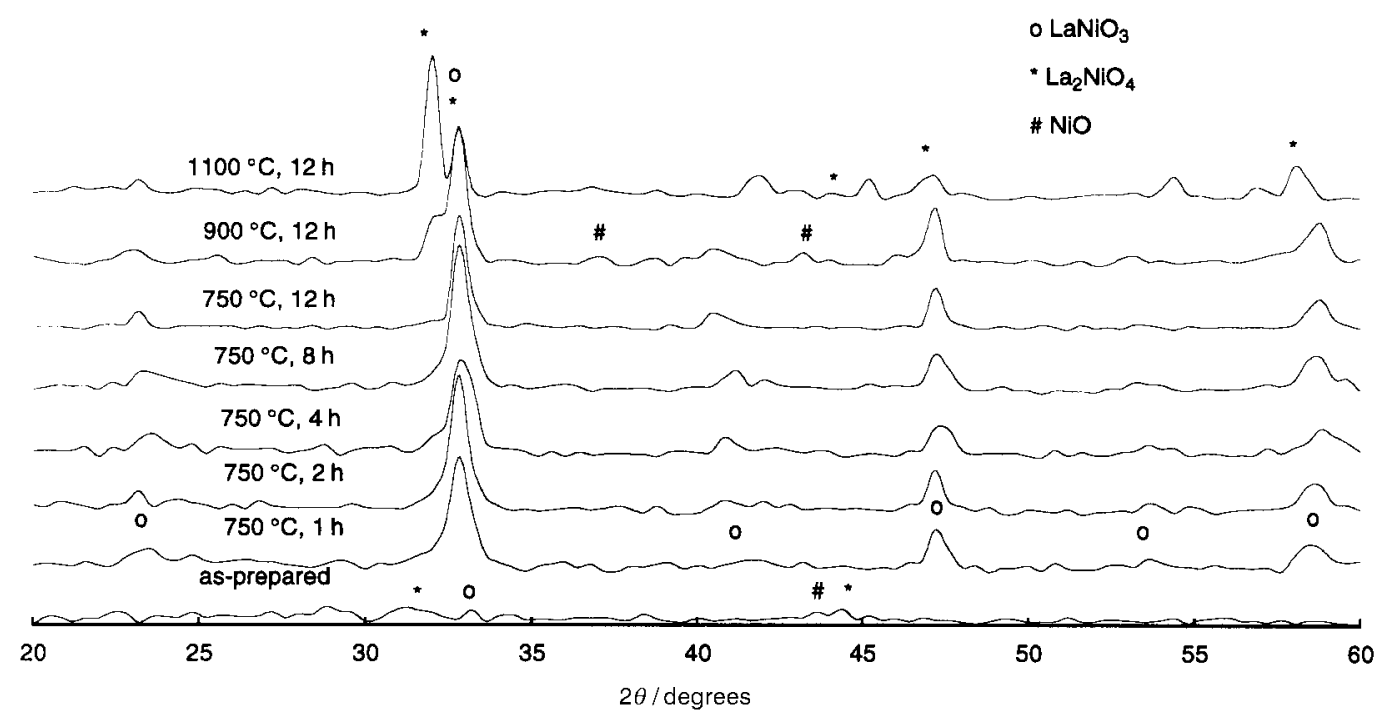

Fig. $1 \mathrm{X}$-Ray diffractograms of $\mathrm{LaNiO}_{(3-\delta)}$ powders, as-prepared and calcined at $750{ }^{\circ} \mathrm{C}$ for $1,2,4,8$ and $12 \mathrm{~h}$, and at 900 and $1100{ }^{\circ} \mathrm{C}$ for $12 \mathrm{~h}$, showing the characteristic peaks of $\mathrm{LaNiO}_{(3-\delta)}$ with rhombohedral symmetry.

Table 2 Equations describing the various chemical reactions that might be involved in the combustion synthesis

\begin{tabular}{|c|c|c|}
\hline Reaction & Descriptive equation & $\Delta H^{\mathrm{o}}\left(25^{\circ} \mathrm{C}\right) / \mathrm{kcal}^{a}$ \\
\hline $\mathrm{R} 1$ & $\mathrm{CO}\left(\mathrm{NH}_{2}\right)_{2(\mathrm{c})}+1.5 \mathrm{O}_{2}(\mathrm{~g}) \Rightarrow \mathrm{CO}_{2}(\mathrm{~g})+2 \mathrm{H}_{2} \mathrm{O}(\mathrm{g})+\mathrm{N}_{2}(\mathrm{~g})$ & -129.9 \\
\hline $\mathrm{R} 2$ & $\mathrm{Ni}\left(\mathrm{NO}_{3}\right)_{2} \cdot 6 \mathrm{H}_{2} \mathrm{O}_{(\mathrm{c})} \Rightarrow \mathrm{NiO}(\mathrm{c})+\mathrm{N}_{2}(\mathrm{~g})+2.5 \mathrm{O}_{2}(\mathrm{~g})+6 \mathrm{H}_{2} \mathrm{O}_{(\mathrm{g})}$ & 124.5 \\
\hline $\mathrm{R} 3$ & $\mathrm{La}\left(\mathrm{NO}_{3}\right)_{3} \cdot 6 \mathrm{H}_{2} \mathrm{O}_{(\mathrm{c})} \Rightarrow 0.5 \mathrm{La}_{2} \mathrm{O}_{3(\mathrm{c})}+6 \mathrm{H}_{2} \mathrm{O}_{(\mathrm{g})}+1.5 \mathrm{~N}_{2}(\mathrm{~g})+3.75 \mathrm{O}_{2}(\mathrm{~g})$ & 171.1 \\
\hline $\mathrm{R} 4$ & $\mathrm{NiO}(\mathrm{c})+0.5 \mathrm{La}_{2} \mathrm{O}_{3(\mathrm{c})}+0.25 \mathrm{O}_{2}(\mathrm{~g}) \Rightarrow \mathrm{LaNiO}_{2}(\mathrm{c})$ & -21.2 \\
\hline R5 & $\mathrm{NiO}(\mathrm{c})+\mathrm{La}_{2} \mathrm{O}_{3}(\mathrm{c}) \Rightarrow \mathrm{La}_{2} \mathrm{NiO}_{4}(\mathrm{c})$ & -0.7 \\
\hline RS1 & $\mathrm{Ni}\left(\mathrm{NO}_{3}\right)_{2} \cdot 6 \mathrm{H}_{2} \mathrm{O}_{(\mathrm{c})}+\mathrm{La}\left(\mathrm{NO}_{3}\right)_{3} \cdot 6 \mathrm{H}_{2} \mathrm{O}_{(\mathrm{c})} \Rightarrow \mathrm{LaNiO}_{3}(\mathrm{c})+12 \mathrm{H}_{2} \mathrm{O}_{(\mathrm{g})}+2.5 \mathrm{~N}_{2}(\mathrm{~g})+6 \mathrm{O}_{2}(\mathrm{~g})$ & 274.4 \\
\hline RS2 & 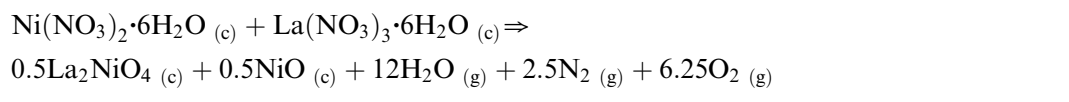 & 295.3 \\
\hline RT1 & $\begin{array}{l}\mathrm{Ni}\left(\mathrm{NO}_{3}\right)_{2} \cdot 6 \mathrm{H}_{2} \mathrm{O}(\mathrm{c})+\mathrm{La}\left(\mathrm{NO}_{3}\right)_{3} \cdot 6 \mathrm{H}_{2} \mathrm{O}_{(\mathrm{c})}+m \mathrm{CO}\left(\mathrm{NH}_{2}\right)_{2}(\mathrm{c})+(1.5 m-6) \mathrm{O}_{2}(\mathrm{~g}) \Rightarrow \\
\mathrm{LaNiO}_{3}(\mathrm{c})+(12+2 m) \mathrm{H}_{2} \mathrm{O}_{(\mathrm{g})}+(2.5+m) \mathrm{N}_{2}(\mathrm{~g})+m \mathrm{CO}_{2}(\mathrm{~g})\end{array}$ & $274.4+m(-129.9)$ \\
\hline RT2 & $\begin{array}{l}\mathrm{Ni}\left(\mathrm{NO}_{3}\right)_{2} \cdot 6 \mathrm{H}_{2} \mathrm{O}_{(\mathrm{c})}+\mathrm{La}\left(\mathrm{NO}_{3}\right)_{3} \cdot 6 \mathrm{H}_{2} \mathrm{O}_{(\mathrm{c})}+m \mathrm{CO}\left(\mathrm{NH}_{2}\right)_{2}(\mathrm{c})+(1.5 m-6.25) \mathrm{O}_{2}(\mathrm{~g}) \Rightarrow \\
0.5 \mathrm{La}_{2} \mathrm{NiO}_{4}(\mathrm{c})+0.5 \mathrm{NiO}(\mathrm{c})+(12+2 m) \mathrm{H}_{2} \mathrm{O}_{(\mathrm{g})}+(2.5+m) \mathrm{N}_{2}(\mathrm{~g})+m \mathrm{CO}_{2}(\mathrm{~g})\end{array}$ & $295.3+m(-129.9)$ \\
\hline
\end{tabular}

accurately described as RT2 $=\mathrm{RS} 2+m \mathrm{R} 1$ (Table 2). A calculation entirely similar to that described above leads to a theoretical temperature reached by all the final products in reaction RT2 of $796^{\circ} \mathrm{C}$. This temperature, although comparable to the one obtained for reaction RT1, is closer to the experimental value of $750^{\circ} \mathrm{C}$ and an indication that the stoichiometric urea content is adequate, if adiabatic conditions prevail. It should be noted, however, that significant heat losses may occur and the actual maximum temperature might well be lower. Also, the short reaction time of $2-3$ min is very much shorter than the $12 \mathrm{~h}$ exposure usually needed at this temperature.

The lanthanum-deficient perovskite $\mathrm{La}_{0.9} \mathrm{NiO}_{(3-\delta)}$ was also prepared by combustion reaction from batches prepared with $\mathrm{Ni}\left(\mathrm{NO}_{3}\right)_{2} \cdot 6 \mathrm{H}_{2} \mathrm{O}, \mathrm{La}\left(\mathrm{NO}_{3}\right)_{3} \cdot 6 \mathrm{H}_{2} \mathrm{O}$ and $\mathrm{CO}\left(\mathrm{NH}_{2}\right)_{2}$ in the molar ratio $0.9: 1: 3.92$. The mixture also ignited easily and, after an equally short reaction time, a dry black foam was also produced. Again, the X-ray diffraction pattern of the asprepared powder showed crystalline $\mathrm{La}_{2} \mathrm{NiO}_{4}$ as the major phase present, together with a small amount of NiO. At this point, it is worth mentioning that $\mathrm{La}_{2} \mathrm{NiO}_{(4+\delta)}$ synthesis by the solid state route normally requires exposure to temperatures in the range $900-1200{ }^{\circ} \mathrm{C}$ for $24 \mathrm{~h}$ and repeated intermediate grinding steps. ${ }^{25}$ The combustion synthesis technique will undoubtedly prove to be a much simpler and more reliable route to synthesize this compound as well.

\section{Powder characterization}

The as-prepared powders were further characterized and the BET specific surface area of the stoichiometric perovskite precursor powder was determined to be $9.5 \mathrm{~m}^{2} \mathrm{~g}^{-1}$. When observed by TEM, individual crystals could be clearly perceived by alternating bright/dark field. Typically, agglomerates of very fine crystals (ca. $10 \mathrm{~nm}$ ) could be seen (Fig. 2), producing the electron diffraction rings shown in the inset in Fig. 2. For the La-deficient perovskite precursor powder, which 


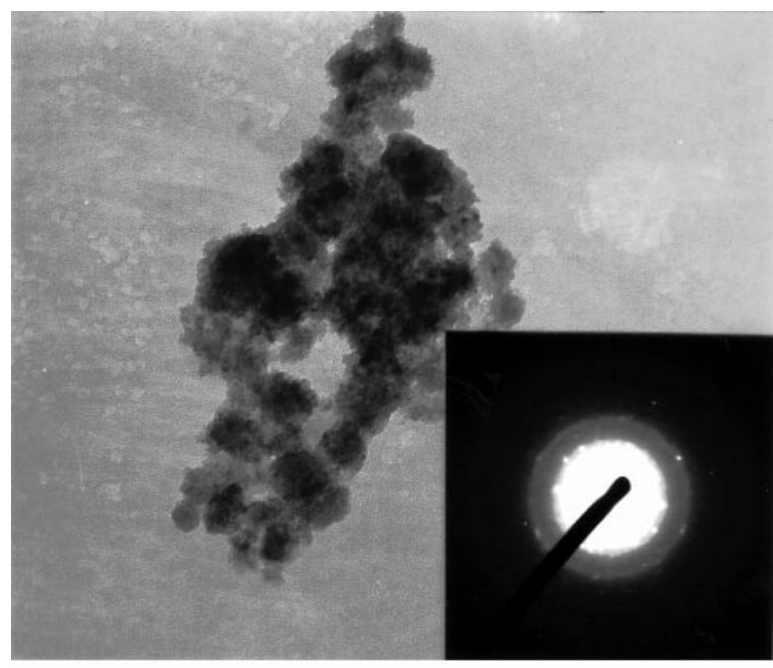

$100 \mathrm{~nm}$

Fig. 2 TEM micrographs of the as-prepared $\mathrm{LaNiO}_{(3-\delta)}$ powders, showing: typical particle agglomerates and (inset) electron diffraction pattern of polycrystals.

is also crystalline, a larger crystallite size of $150 \mathrm{~nm}$ was found and a BET specific surface area of $8 \mathrm{~m}^{2} \mathrm{~g}^{-1}$ was obtained.

The powders were then subjected to a temperature of $750{ }^{\circ} \mathrm{C}$ for successively longer periods of time (namely, 1, 2, 4, 8 and $12 \mathrm{~h}$ ), and investigated by X-ray diffraction. The corresponding diffractograms (Fig. 1) show that the $\mathrm{LaNiO}_{(3-\delta)}$ perovskite is readily produced, with crystallinity increasing with increasing time at the temperature. The perovskites were found to be stable after $12 \mathrm{~h}$ exposure to higher temperatures $(900$ and $1100^{\circ} \mathrm{C}$ ), as shown by the corresponding X-ray diffractograms also presented in Fig. 1, although the stoichiometric perovskite seems to present a narrower stability range. From the X-ray diffraction patterns of single phase powders calcined at $750{ }^{\circ} \mathrm{C}$ for $8 \mathrm{~h}, a$ and $c$ lattice parameters (hexagonal structure) were calculated and found to be in good agreement with published values, ${ }^{26,27}$ namely, $a=0.5464(1)$ and $c=0.65854(2) \mathrm{nm}$ for the stoichiometric perovskite, and $a=0.5454(1)$ and $c=0.65799(2) \mathrm{nm}$ for the La-deficient perovskite.

After $12 \mathrm{~h}$ at $750{ }^{\circ} \mathrm{C}$, the powder density was determined to be $7.12 \times 10^{3} \mathrm{~kg} \mathrm{~m}^{-3}$ for the calcined stoichiometric perovskite and $5.56 \times 10^{3} \mathrm{~kg} \mathrm{~m}^{-3}$ for the La-deficient perovskite. The typical calcined powder morphology can be observed in the SEM micrograph shown in Fig. 3. The BET specific surface area of the stoichiometric perovskite decreased to $4.5 \mathrm{~m}^{2} \mathrm{~g}^{-1}$ and the corresponding average particle size was found to be $6.9 \mu \mathrm{m}$, within a monomodal grain size distribution [Fig. 4(A)]. As for the La-deficient perovskite, after the same heat treatment the BET specific surface area was determined to be $4.7 \mathrm{~m}^{2} \mathrm{~g}^{-1}$ and an average particle size of $10 \mu \mathrm{m}$ was obtained, within a bimodal grain size distribution [Fig. 4(B)]. The narrow particle size distribution of the calcined stoichiometric powder, practically monosized, suggests that it might display low packing densities although its high specific surface area should ensure good sinterability. The submicron features of the asprepared powders on the other hand, promote densification but associated with unsuitable powder morphology and poor powder packing might cause abnormal grain growth and hinder densification (the driving free energy for mass transport is inversely proportional to particle size, but rapid grain growth by boundary motion and not via surface diffusion only occurs when the body density is greater than $90 \%$ ).

The thermal analyses (DTA) of the as-prepared combustion powders showed as their salient features an endothermic peak at $750{ }^{\circ} \mathrm{C}$ which was attributed to the nucleation of the

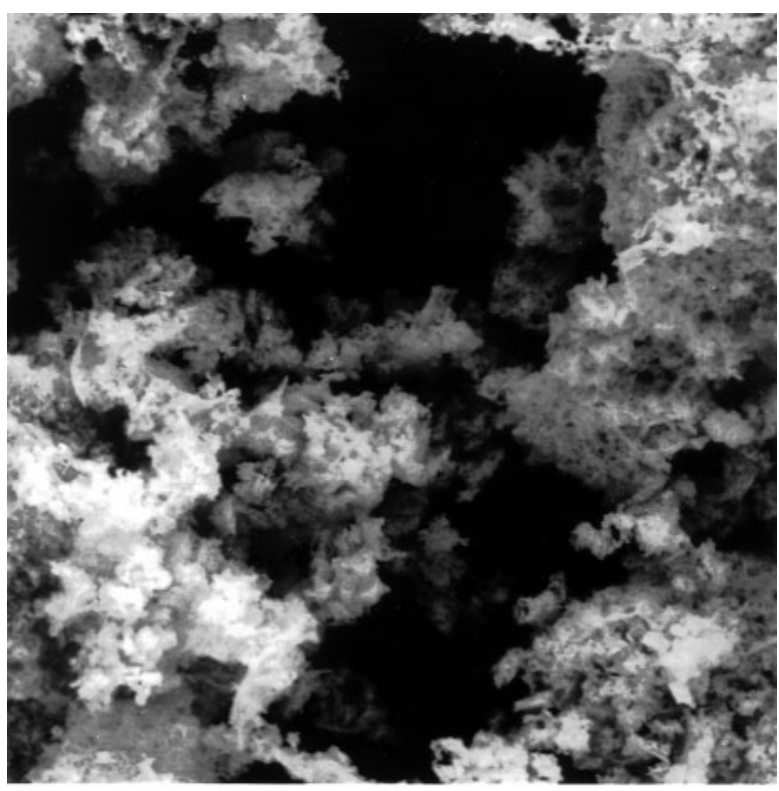

$5 \mu \mathrm{m}$

Fig. 3 Typical calcined powder morphology as seen with SEM $\left(\mathrm{LaNiO}_{(3-\delta)}, 750^{\circ} \mathrm{C}, 12 \mathrm{~h}\right.$, in air).
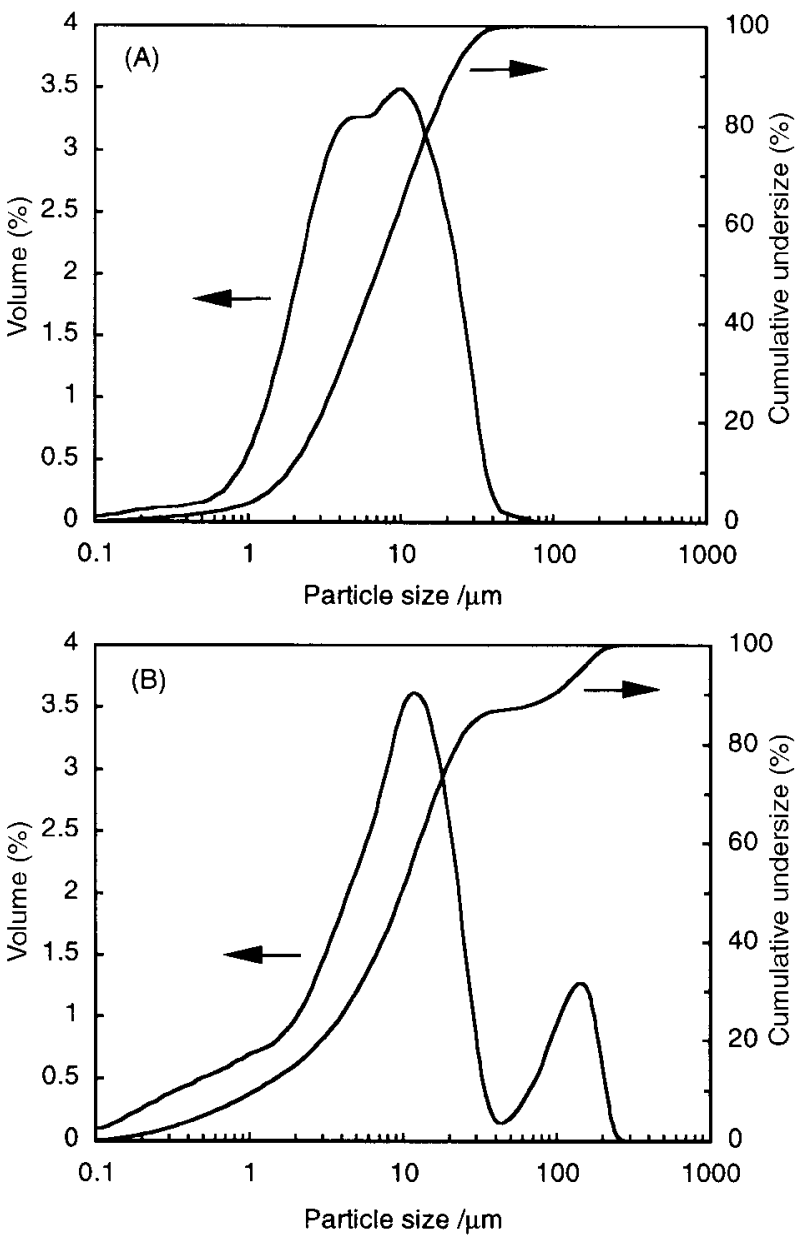

Fig. 4 Particle size distribution of the perovskite powders after calcining at $750{ }^{\circ} \mathrm{C}, 12 \mathrm{~h}$ : (A) $\mathrm{LaNiO}_{(3-\delta)}$ and (B) $\mathrm{La}_{0.9} \mathrm{NiO}_{(3-\delta)}$.

perovskite phase. The dilatometry study carried out on the asprepared powders (Fig. 5) showed that the shrinking rate peaks first at 725 , then at 980 and finally at $1225^{\circ} \mathrm{C}$. The X-ray 


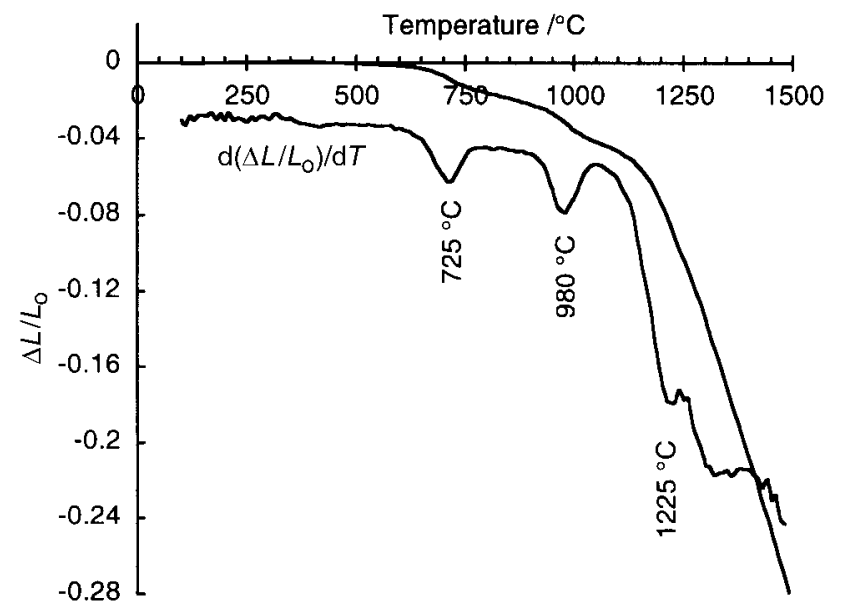

Fig. 5 Dilatometric curves obtained with the as-prepared powders, highlighting the changes in shrinking rate as a function of temperature ( $L$ is the length of the test piece, $L_{0}$ being the initial length).

diffractogram of the powder calcined at $725^{\circ} \mathrm{C}$ already showed the presence of crystalline perovskite, although with cubic symmetry, and still containing some $\mathrm{La}_{2} \mathrm{NiO}_{4}$. Thus, the first maximum in the shrinking rate can be attributed to perovskite phase formation, confirming the DTA results. The second maximum in the shrinking rate could be attributed to a significant oxygen loss as the perovskite changes from cubic to rhombohedral symmetry (the oxygen deficiency was determined as weight gain in oxygen after $3 \mathrm{~h}$ at $900{ }^{\circ} \mathrm{C}$, and the values obtained were $\delta=0.05$ for $\mathrm{La}_{(1-x)} \mathrm{NiO}_{3-\delta}$, and $\delta=0.03$ for $\mathrm{LaNiO}_{3-\delta}$; these figures are below the range of $0.10-0.18$ reported in the literature). ${ }^{9,11}$ The last maximum corresponds to the decomposition of the perovskite into $\mathrm{La}_{2} \mathrm{NiO}_{4}$ and other $\mathrm{La}$ and $\mathrm{Ni}$ mixed oxides.

The electrophoretic studies carried out showed that the stoichiometric perovskite has an isoelectric point near $\mathrm{pH} 2$ reaching a stable zeta potential of $c a .-50 \mathrm{mV}$ above $\mathrm{pH} 7$ (Fig. 6). According to the DLVO theory, powder suspensions show colloidal instability near the isoelectric $\mathrm{pH}$ (i.e. they flocculate) and they are stable away from that $\mathrm{pH}$ value. For practical purposes, a repulsive potential greater than \pm 30 $40 \mathrm{mV}$ is needed to guarantee a well dispersed suspension. ${ }^{28}$ The above result shows that aqueous suspensions of the stoichiometric perovskite are fully dispersed and adequate for further processing (e.g. electrode deposition) at neutral $\mathrm{pH}$.

\section{Conclusions}

This work shows that the valency based molar proportions of reactants proposed by propellant chemistry can be conveni-

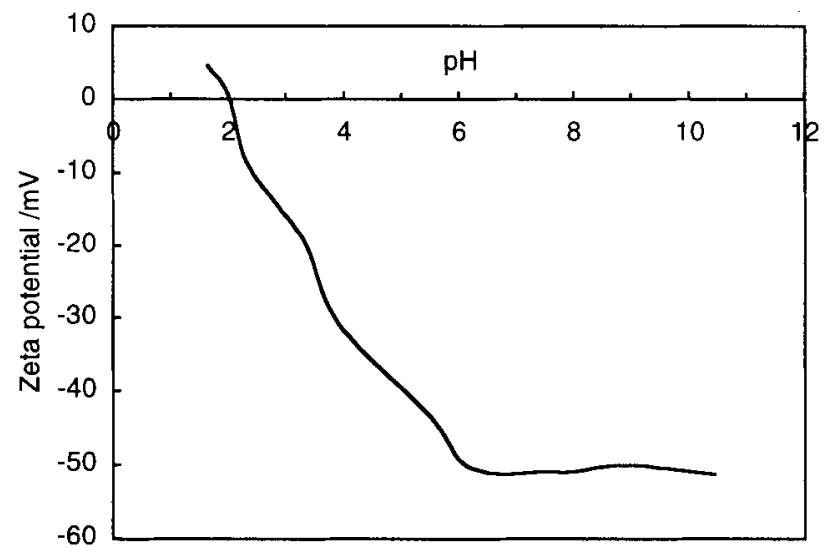

Fig. 6 Typical zeta potential vs. $\mathrm{pH}$ curve for calcined powders suspended in distilled water $\left(\mathrm{LaNiO}_{(3-\delta)}, 750^{\circ} \mathrm{C}, 12 \mathrm{~h}\right.$, in air). ently used to successfully produce adequate $\mathrm{La}-\mathrm{Ni}$ perovskite precursors, with good compositional control and homogeneity, which readily transform to crystalline perovskite at low temperatures over short calcination times. In fact, the synthesis of the $\mathrm{La}_{(1-x)} \mathrm{NiO}_{3-\delta}(x=0$ and 0.1$)$ perovskites is readily achieved by calcining the as-prepared combustion-produced powder precursors at $750^{\circ} \mathrm{C}$ for just $1 \mathrm{~h}$, whereas other synthetic methods require exposures of at least $12 \mathrm{~h}$. This is, no doubt, a consequence of the atomic level homogeneity of the combustion-produced powders. Like various other methods that have been proposed and used to prepare ceramic powders, the combustion synthesis route enables synthesis at low temperatures and the products obtained are in a finely divided state with large surface areas. Unlike other methods, combustion synthesis offers the added advantages of simplicity of the experimental set-up, a surprisingly short time period between the preparation of the reactants and the availability of the final product, savings in external energy consumption and the equally important potential for simplifying the processing prior to forming, providing a simple alternative to other more elaborate techniques.

Even after $12 \mathrm{~h}$ at $750{ }^{\circ} \mathrm{C}$, and despite grain growth, the combustion perovskites still presented specific surface areas in the order of $4.5 \mathrm{~m}^{2} \mathrm{~g}^{-1}$, due to the original very fine particle size, whereas powders produced by the solid state ceramic route typically present values of the order of $0.5 \mathrm{~m}^{2} \mathrm{~g}^{-1}$. This result suggests that a much higher catalytic activity can be expected from combustion perovskites compared with similar powders produced by alternative routes. The high homeogeneity of the as-prepared combustion powders also explains the higher thermal stability observed for these perovskites (i.e. in the 750$1100{ }^{\circ} \mathrm{C}$ temperature range used in the manufacture and/or service of SOFCs, PEMFCs and MCFCs) with no signs of segregation of $\mathrm{La}_{2} \mathrm{O}_{3}$, a problem commonly displayed by perovskites produced by alternative techniques.

It is also worth mentioning that the major phase present in the as-prepared combustion powders is crystalline $\mathrm{La}_{2} \mathrm{NiO}_{4}$ whose synthesis by the solid state route requires exposure to temperatures in the range $900-1200{ }^{\circ} \mathrm{C}$ for $24 \mathrm{~h}$ and repeated intermediate grinding steps. Again, the combustion synthesis technique will undoubtedly be a much simpler and more reliable route to synthesize this compound.

The $\mathrm{pH}$ dispersion range of the perovskites aqueous suspensions was found to be broad and around $\mathrm{pH} 7$, which results in a rather forgiving suspension preparation step prior to further processing.

\section{Acknowledgements}

This work was partially funded by JNICT-Portugal (PRAXIS XXI Ph. D. grant BD/11131/97), by Fundación Caja de Madrid-Spain (post-doctoral scholarship) and by EC/JOULE project JOE3CT9760049.

\section{References}

1 R. J. H. Voorhoeve, in Advanced Materials in Catalysis, ed. J. J. Burton and R. L. Garten, Materials Science Series, Academic Press, New York, 1977, ch. 5.

2 J. Happel, in Base Metal Oxide Catalysis, ed. J. Happel, M. Hnatow and L. Bajars, Marcel Dekker, New York, 1977, ch. 4.

3 R. J. H. Voorhoeve, D. W. Johnson Jr., J. P. Remeika and P. K. Gallagher, Science, 1977, 195, 827.

4 Y. Matsumoto, H. Yoneyama and H. Tamura, Chem. Lett., 1975, 661 .

5 Y. Matsumoto, H. Yoneyama and H. Tamura, J. Electroanal. Chem., 1975, 80, 115 .

6 J. L. G. Fierro, J. M. D. Tascón and L. González Tejuca, J. Catal., $1985,93,83$.

7 J. M. D. Tascón, S. Mendioroz and L. González Tejuca, Z. Phys. Chem. N. F., 1981, 124, S109.

8 A. C. C. Tseung and H. L. Beran, J. Mater. Sci., 1970, 5, 604. 
9 J. Takahashi, T. Toyoda and M. Takatsu, J. Mater. Sci., 1990, 25, 1557.

10 S. P. Skaribas, P. J. Pomonis and A. T. Sdoukos, J. Mater. Chem., 1991, 1, 781.

11 L. M. Gan, H. S. O. Chan, L. H. Zhang, C. H. Chew and B. H. Loo, Mater. Chem. Phys., 1994, 37, 263.

12 S. S. Manoharan and K. C. Patil, J. Am. Ceram. Soc., 1992, 75, 1012.

13 P. Ravindranathan, S. Komarneni and R. Roy, J. Mater. Sci. Lett., 1993, 12, 369

14 Y. Zhang and G. C. Stangle, J. Mater. Res., 1994, 9, 1997.

15 M. Muthuraman, N. Arul Dhas and K. C. Patil, J. Mater. Synth Process., 1996, 4, 115 .

16 D. A. Fumo, M. R. Morelli and A. M. Segadães, Mater. Res. Bull., 1996, 31, 1243.

17 D. A. Fumo, J. R. Jurado, A. M. Segadães and J. R. Frade, Mater. Res. Bull., 1997, 32, 1459.

18 A. M. Segadães, M. R. Morelli and R. G. A. Kiminami, J. Eur. Ceram. Soc., 1998, 18, 771.

19 A. Cüneyt Tas, J. Am. Ceram. Soc., 1998, 81, 2853.

20 S. R. Jain, K. C. Adiga and V. R. Pai Verneker, Combust. Flame, 1981, 40, 71 .
21 Lange's Handbook of Chemistry, 12th edn., ed. J. A. Dean, McGraw-Hill, New York, 1979.

22 CRC Handbook of Chemistry and Physics, 66th edn., ed. R. C. Weast, M. J. Astle and W. H. Beyer, CRC Press, Boca Raton, FL, 1985.

23 H. Nagamoto, I. Mochida, K. Kagotani and H. Inoue, J. Mater. Res., 1993, 8, 3158.

24 H. Yokokawa, N. Sakai, T. Kawada and M. Dokiya, J. Electrochem. Soc., 1991, 138, 2719.

25 K. Ishikawa, W. Shibata, K. Watanabe, T. Isonaga, M. Hashimoto and Y. Suzuki, J. Solid State Chem., 1997, 131, 275.

26 J. M. Gonzalez-Calbet, M. J. Sayagues and M. Vallet-Regi, Solid State Ionics, 1989, 32, 721.

27 S. Rakshit and P. S. Gopalakrishnan, J. Solid State Chem., 1994, 110, 28.

28 Surface and Colloid Chemistry in Advanced Ceramics Processing, ed. R. J. Pugh and L. Bergstrom, Surfactant Science Series Vol. 51, Marcel Dekker, New York, 1994.

Paper $9 / 02808 K$ 